\title{
The Communication Accommodation Among Bima Students in Mataram
}

\author{
Sarif Hidayat \\ Mataram University \\ NTB, Indonesia \\ sarifh400@gmail.com
}

\begin{abstract}
Communication accommodation between Bima students in Mataram is a research that aims to find out the ways to accommodate communication between Bima students in Mataram. This research used qualitative descriptive design. The samples of this research are Bima students in Mataram. The data were collected by using observation and interviews. This research applied descriptive data analysis. It shows that in communication, Bima students used code-switching and codemixing as a way to facilitate the communication process, while in the way of accommodations, they tended to use convergence. However, divergence and excessive accommodation were also used by some students for certain reasons.
\end{abstract}

Keywords - communication, accommodation, Bima students

\section{INTRODUCTION}

\section{A. The Basic Concepts of Communication}

Communication is a fundamental thing for human life. Communication makes human life easy as individuals and social beings in society. Hovland [1] defines communication as a process by an individual (communicator) to transmit stimulus (usually verbal symbols). The process by (communicator) communicates stimulus (usually a symbol of language) to change the behavior of others (communicant). In communication, there is human interaction that mutually affects each other intentionally or unintentionally. So that the communication is related to human behavior and satisfaction of the requirement for interacting with other people. Mulyana and Rachmat [2] explain that the ways we communicate, the conditions of our communication, the language and style of language we use, and our nonverbal behaviors, is mainly a response to the function of our culture. Communication is bound by culture. Every human being has different culture. Thus, the implementation and behavior of individual communication based on the culture will be also different.

\section{B. The Existence of Communication in Social Life}

In its development, communication is not only conducted by several people in one community group, but also between groups of people who have different ways to communicate. Referring to [3], there are two causes of differences in the way of communication between one community and another community, namely the identity and solidarity of the community group. Identity is divided into two parts, namely personal identity and social identity (ethnicity), while solidarity is divided into two parts, namely social solidarity and solidarity linguistics. Kamaludin states that personal identity is seen as form of individual embodiment of cultural values. Individuals can have individual perspectives about themselves even though personal identity is obtained in social relationships. Social identity (ethnicity) is very influenced by social constructionist philosophy that can bring someone back as Webber (stated in [3]) states that the formation of ethnic groups based on the same beliefs are considered as common descendants. Then social solidarity is a sociological term that is defined as the process when someone wants to unite and act as coherent and united force. While the use of linguistic solidarity has been studied in a number of contexts and settings. Other researchers have seen solidarity not only as language and linguistic form but also as representation of the activities that appear in the conversational interaction.

The different ways of communicating because of the effects of social situations and conditions also happen in West Nusa Tenggara province which involves three tribes, namely the Mbojo (Bima, Dompu), Samawa (Sumbawa) and Sasak (Mataram, Lombok) tribes. Currently, Mataram city is destination for someone who wants to continue their education in college (undergraduate and postgraduate) because it has many universities. Students in Mataram city come from Bima City, Dompu Regency, Sumbawa Regency, and Lombok Island. However, data showed that the majority of students in Mataram city come from Bima city.

Based on this conditions, it is interesting to examine how Bima students in Mataram communicate among themselves, as well as with non-Bima people, especially with Sasak people. The current situation is that most people use the Sasak language in Mataram city. This situation causes the Bima students often hear foreign languages that they do not understand so that it creates curiosity to understand the language in order that they will socialize with the Sasak people more easily. Therefore, they usually listen to or hear the Sasak language in their daily lives but they do not forget about Bima language because in Mataram city there are many Bima students who live together. This became something interesting when several Bima and non-Bima students gathered. This condition requires Bima students to adapt themselves between Bima and non-Bima students in order that communication process goes well and smoothly.

\section{Communication Accommodation Theory}

Howard Giles was the first person to discover the theory of communication accommodation in 1973. At that moment Giles introduced his thoughts on the model of "mobility accent" which is based on a variety of accents that can be heard in an interview situation. Communication 
accommodation theory suggests that individuals use communication to show their attitudes toward each other. The constant movement that leads up and avoids from others, by changing the behavior of someone who is communicating is called accommodation.

According to the communication accommodation theory, someone is motivated to use language in different ways in order to achieve the desired level of social distance between speaker and listener [4]. One of the basic principles of communication accommodation theory is that communicators use specific communication strategies, namely convergence and divergence, to indicate their attitudes towards each other and their respective of social groups. Convergence can be defined as an individual's strategy of adjusting communicative behavior on one or number of linguistic, paralinguistic, and nonverbal features in such a way that it becomes more similar to the behavior of the interlocutor. The divergence refers to the way speakers of speech and nonverbal emphasize the difference between themselves and others. Divergences are designed to emphasize the distinctiveness of one's interlocutors, usually based on group membership.

\section{RESEARCH METHOD}

This is a qualitative descriptive research that aims to find out the communication accommodations between Bima students when communicating with each other in Mataram. The respondents of this research were the Bima students in Mataram and the data collection techniques used observation and in-depth interviews with respondents. Researchers observed and asked questions about the use of language by Bima students when communicating. Data analysis was conducted based on observations and interviews about the use of language by Bima students when communicating with each other. This study used the Miles and Huberman model for data analysis which includes four steps, namely: Data Collection, Data Reduction, and Conclusion.

\section{RESULTS AND DISCUSSION}

This study explains the communication accommodation process conducted by Bima students in Mataram. In the process, communication becomes the media to form of identity and also change the mechanism. A person's identity is formed when interacting socially with others. The people get their views and reactions of others in social interaction and conversely, showed a sense of identity and the way others express themselves and responding to others [5]. While the accommodation is defined as the ability to customize, modify, or adjust someone behavior to respond others people [6]. Furthermore, accommodation appears because of desire to respect the other person by shifting the native language towards the other person's style.

The essence of the theory of this accommodation is the adaptation of someone in communicating with other people. Communication accommodation theory states that in every communication accommodation process there are strategies used by communicators and communicants to stabilize the communication process that is conducted so that communication goes well and creates harmonious relationships, namely the strategy of convergence, divergence, as well as the result of the process of accommodation there will be label given by the listener to the speaker that is labeled excessive accommodation [7].

Based on the research conducted, it appears that several conditions occur when Bima students communicate with each other, as follows:

\section{A. Language Choices}

Based on the research results, the languages often used are Bima and Indonesia languages.

First, the use of dominant language is Bima language because Bima students tend to live in groups. Another factor is that there is general mindset in which communicating not using Bima language is an arrogance that causes Bima students to be reluctant to communicate. However, this mindset began to change when there were Bima students who have been in Mataram for a long time and have good organizational experience so that some of them tend to use Indonesian when communicating in groups.

Second, the use of Indonesian among Bima students because of the awareness when there are non-Bima students (Sasak, Samawa, Flores, and others) gather with them to respect the differences in language and ethnicity. In addition, they will also communicate in Indonesian when they are in an official forum and other students with family backgrounds and environments who speak Indonesian, for example some Bima students from Bima City. This affects other Bima students to communicate by using Indonesian when they interact.

\section{B. Phonological Aspects}

In the phonological aspect, the Bima students uttered the word that has the phoneme ' $\mathrm{e}$ ' which is not according to the rules of phonology. They utter the 'e' phoneme in long sound and uncontrolled way, for example in the words of 'bensin, bebas, beri, perlu, and so on'. When communicating, especially using Indonesian, Sasak or other languages, they tend to utter the word with the Bima version, especially in an unconscious condition. It shows that there is divergence in communication. However, communication between Bima students do not always show uniqueness, but they also try to converge words that contain the phoneme 'e' correctly according to the pronunciation based on awareness of the topic of conversation and the time period staying in Mataram.

\section{Aspects of Using Code-Switching and Code-Mixing}

Bima students applied the code-switching and codemixing in communicating as a form of adjustment to the interlocutor, and it was done because they were having difficulty in uttering words in the language used. The purpose of code-switching is to change the type of language used in communication. It is caused by two reasons: first, when the conversation involves only Bima students, and second, conversations conducted only by Bima students then suddenly non-Bima students came to join. At that time they immediately switched the language from Bima language to Indonesian. 
While the code-mixing occurs when the conversation between Bima students tend to insert Indonesian words when communicating with Bima language. Conversely, when communicating using the Indonesian language, it tends to insert Bima language. This happens because of some of the words that must implement the code-switching to explain the intent of the speaker.

\section{Convergence, Divergence and Excessive Accommodation}

The results of the research described above indicate that communication accommodation among Bima students in Mataram involves 3 conditions, namely convergence, divergence and excessive accommodation. Convergence is seen directly from the use of the Bima language when meeting between Bima students. In addition, they will adapt the use of language when they find out the other person is accustomed to using Indonesian, whereas if they are with non Bima students, they will adapt to use Indonesian.

Further, the divergence condition can be seen from some Bima students who insist on using Bima language when the interlocutor uses Indonesian on certain occasions. They said that communicating in Indonesian among Bima students could bring awkwardness and feel uncomfortable so that it was considered to use Bima language. On the contrary, there are some students who tend to insists on using the Indonesian when the speaker uses the Bima language, because some students are familiar with the use of Indonesian language in communication.

The last is excessive accommodation, in which the Bima students uttered the word that has the phoneme ' $\mathrm{e}$ ' in the way which is not according to the rules of phonology. They utter the ' $e$ ' phoneme in long sound and uncontrolled way so that the sounds become strange. It happens because the enthusiasm for converging interlocutors is very high without concern to the provisions of the correct pronunciation of words and unconsciousness when communicating.

\section{CONCLUSION}

Accommodation is the ability to adjust, modify, or organize someone behavior in response to another person. Accommodation leads to the ways of individuals in monitoring interactions and may adapt their behavior during the interaction. The communication accommodations among Bima students in Mataram are quite varied, they use code switching and code mixing to facilitate communication when they found obstacles in expressing certain words. In accommodating, they show the dominant way of convergence, which is to adapt how to communicate with others. Convergence among Bima students is a form of mutual identity, character and culture that understands each other.

The same thing happened to non-Bima students. In daily life, especially in the environment of Bima students, they use the Bima language dominantly. Meanwhile, the Indonesian language is used as common language when in official forums and when gathering with Sasak students in order to understand each other. However, divergence and excessive accommodation still occur when communicating. The divergence occurs because it has strong sense that Bima students always use Bima language even though there are non-Bima students around and they feel superior in using Indonesian when the other person uses the Bima language. Whereas excessive accommodation occurs because of high enthusiasm in uttering the phoneme 'e' by over-controlling so they produce strange sounds which are not according to the rules of correct word pronunciation.

\section{REFERENCES}

[1] D. Mulyana, Ilmu Komunikasi Suatu Pengantar [Communication Scince: An introduction]. Bandung: PT. Remaja Rosdakarya, 2008.

[2] D. Mulyana and J. Rakhmat, Komunikasi Antarbudaya [Intercultural communication]. Bandung: Remaja Rosdakarya, 2014.

[3] K. Yusra, Language and Social Solidarity (A New Horizon in the Study of Language of Social Realities). Mataram: Lembaga Cerdas Press, 2012.

[4] H. Giles and K. A. Noels, Communication Accommodation in Intercultural Encounters". Reprinted in L. Chen (Ed.), Culture, cultures and intercultural communication: A cross disciplinary reader. Shanghai: Shanghai Foreign Language Education Press, in press, 2007.

[5] S. W. Littlejohn and K. A. Foss, Communication Theory. California: Sage Publications, 2009.

[6] R. West and L. H. Turner, Introducing Communication Theory: Analysis and Application 6th ed. New York: McGraw-Hill Education, 2019

[7] H. Giles and T. Ogay, Communication Accomodation Theory. Santa Barbara: University of California, 2007. 